\title{
Formative Assessment: Opportunities and Challenges
}

\author{
Liqiu Wei \\ Department of Foreign Languages and literature, Hechi University, Yizhou, Guangxi, China \\ Email: lisawlq@yahoo.com.cn
}

\begin{abstract}
As a learning tool, formative assessment has attracted the attention of more and more researchers. Based on the writer's own innovation with the tool and relevant research, this paper first describes the use of formative assessment in college English classrooms in China, then provides recommendations and discusses future directions.
\end{abstract}

Index Terms - formative assessment (FA), college English classrooms, learner autonomy

Dissatisfaction with traditional assessment practices is widespread. Around the globe, educators are beginning to pay more attention to the assessments teachers use in classrooms on a daily basis as a powerful lever for raising student achievement. Many nations such as New Zealand, Scotland, England, and the United States have developed government-sponsored "Assessment for Learning" programs (Olson, 2005). In their search for alternative assessment practices, educators and practitioners have looked toward formative assessment (FA) as a foundation for improvement. Over the past two decades, a substantial body of research has been conducted to study FA globally (e.g., Gibbs \& Simpson, 2004; Pausch \& Popp, 1997; Black \&William, 1998a/b; Ministry of Education, New Zealand, 1994; Guo \& Yang, 2003; ARG, 1999; Xu, 2003; xue 2006; Zou \& Cai, 2006). As an English teacher in a university in an underdeveloped Western area in China, in response to the College English teaching reform in China, I have also tried the implementation of FA in my classrooms. In this article, I will describe FA use in Chinese college English classrooms, provide recommendations and discuss future directions.

\section{DEFINITION AND CHARACTERISTICS}

FA, in its simplest form, is seen as formative and an assessment for learning. According to Ministry of Education, New Zealand (1994), in which assessment for learning has been an integral part of the national assessment strategy since 1999 (Olson, 2005), FA is defined as a range of formal and informal assessment procedures (for example, the monitoring of children's writing development, anecdotal records, and observations) undertaken by teachers in the classroom as an integral part of the normal teaching and learning process in order to modify and enhance learning and understanding. Cowie and Bell (1996) defined it as the process used by teachers and students to recognize and respond to student learning in order to enhance that learning, during the learning. In the extensive literature review Inside the black box, Black \& William (1998b) put it as follows:

Assessment' refers to all those activities undertaken by teachers, and by the students in assessing themselves, which provide information to be used as feedback to modify the teaching and learning activities in which they are engaged. Such assessment becomes 'formative assessment' when the evidence is actually used to adapt the teaching to meet the needs. (p.2)

These definitions indicate that formative assessment encompasses teacher observation, classroom discussion, and analysis of student work, including homework and tests. Specifically, FA strategies and techniques can range from engineering more-effective classroom discussions and questions, to providing more-specific feedback on students' papers, to engaging students in critiquing their own learning and that of their peers. And all those definitions and strategies share two characteristics: their results are used primarily to shape and adjust what happens next in classrooms, rather than to provide a grade or mark; and they aim to encourage, not discourage, student effort (Olson, 2005).

Drawn from the above definitions, FA has the following characteristics:

Multi-assessors: Teacher assessment, peer assessment and self assessment are all involved in the process of learning.

Multi-assessing strategies and tools available: Testing and non-testing assessments, formal and informal procedures, numerous non-testing strategies, including classroom observations, portfolios, questionnaires, interviews, student conference and the like.

More comprehensive in assessed contents: It not only assesses cognitive process (mastery of knowledge), but is concerned about learner feelings, behaviours, interests and attitudes.

Developmental and personalized: FA is process-focused and for developmental purpose, not for comparison or selection. It pays more attention to the change in individual learners and respects learner differences and gives full play to learner potentials. 


\section{USE OF FA IN COLLEGE ENGLISH CLASSROOMS}

Much research literature home and abroad has shown the positive impacts of formative assessment on student learning. For example, Black and William (1998a) conducted an extensive research review of 250 journal articles and book chapters winnowed from a much larger pool to determine whether FA raises academic standards in the classroom. Their findings show that efforts to strengthen FA produce significant learning gains as measured by comparing the average improvements in the test scores of the students involved in the innovation with the range of scores found for typical groups of students on the same tests. Effect sizes ranged between 0.4 and 0.7 , with FA apparently helping low-achieving students, including students with learning disabilities, even more than it helped other students (Black \& William, 1998b). Tan's (2004) empirical research has revealed that formative assessment is more effective than summative assessment to aid adult learners to master meta-cognitive strategies, strengthen students 'motivation, form positive affect and improve students' performance in tests. These findings are assumed to be of great help for Chinese English learners because, of all the courses taken by college non-English majors, English can be said to be the course with the most low-achieving students, especially in colleges and universities in Western China: every year so many students enrolled in colleges with quite low English marks, so many students fail in the English final exams, so many students re-do CET-4 time and again. So if formative assessment can really raise student academic achievements, it is well worthwhile to be tried in the Chinese College English teaching context.

Motivated by the previous research home and abroad, in response to the requirements of the new round of College English teaching reform in China, I tried to implement FA into Chinese College English classrooms through action research to improve students learning process. In this innovation, I combined FA and summative assessment, making FA and summative assessment weigh half respectively in the final score portion of the English course. My so doing is just because formative assessment and summative assessment are interactive and they seldom stand alone in construction or effect (Gipps, McCallum \& Hargreaves, 2000) and assessment requires attention to outcomes but also and equally to the experiences that lead to those outcomes (Pausch \& Popp, 1997).

After 3 semesters' circular action research with altogether 227 students from 4 different majors, data collected from questionnaires, interviews, portfolio scripts, final reflection report scripts, and English final examinations have proved that the application of FA in College English classrooms does benefit students and it is really an assessment that strengthens students' intrinsic motivation. It is not only a tool for students to take responsibility for their own learning effectively, but a management tool for teachers to monitor students learning and make instructional adjustments, such as re-teaching, trying alternative instructional approaches, or offering more opportunities for practice (Black \& William, 1998a).

Specifically, findings can be summed up as follows:

First, it helps learners better understand the importance and the role of self evaluation in their learning. Through self evaluation, they know better their weaknesses and strengths, the gap between their current situation and their desired goal, the success criteria and thus make them take action to close the gap.

Second, it is an effective means to strengthen and sustain students' motivation and effort and help build up low-achieving learners' self esteem. The variety of FA activities, either required or optional, provides a space and a platform for students to think and to perform creatively, to assert themselves fully. The multiple assessing agents provide them with opportunities of learning from others besides the teacher, opportunities of doing self reflection and evaluation and thus lead to self development. The combination of FA and summative assessment, and peer/self assessment results weighing in a certain portion in the final score can sustain learners' motivation, making them feel every effort is worth taking.

Third, it makes students' learning strategies change from singular to multiple. Other than memorizing CET-4 vocabulary list and doing CET4 practice tests, more cognitive and meta-cognitive strategies such as setting goals and plans, self reflection, cooperative learning, Internet chatting in English are effectively adopted.

Fourth, it fosters student independent learning. FA takes into account any effort and progress students make, which leads to their autonomous extracurricular English learning. The extracurricular English learning not only makes up for the insufficient classroom learning time but leads to the variety of their language input channels, the larger amount of language input, and wider range of knowledge. Furthermore, it makes students pay more attention to the learning process and the cultivation and development of their comprehensive practical skills.

Last, FA, if used appropriately and persistently, can raise student English achievements. This finding is more obvious with those classes taught by more experienced teachers.

Besides the major findings listed above, the study also produced some other findings. For example, most students like their own portfolios very much, and want to keep them by themselves because "the portfolios bring me a sense of achievement" (student Interview). In terms of assessed tasks, students prefer more challenging and creative learning tasks such as oral presentation, movie response, mini-survey, group work and dislike mechanical learning items such as memorizing texts, copying words and phrases from the course books. Collaborative learning tasks enhance team work spirit and improve the relationship among students. Competition awareness between groups begins to form. Group members collaborate and coordinate for successful performance in class. Oral presentation, paired-dictation and paired-interview encourage more and more students to improve their pronunciation and intonation which tends to be neglected by non-English-majors. 


\section{RECOMMENDATIONS AND PROSPECTS}

Current literature and practitioner reports cited throughout this article and my innovation indicate that educators and frontline teachers will continue to explore and develop formative assessment and the prospects for its use are promising. However, considering its acknowledged limitations characterized by time-consuming, labor extensive, low reliability (Xu, 2003; Zou \& Cai, 2006; xue 2006), technical and professional (Xu, 2003), medium-long-term effect, those potential advantages and empowering impacts on students' learning will not occur on their own. Thus, recommended practices or initiatives to advance the use of FA are presented here.

1. Joint efforts and collaborative work and effective use of self and peer evaluation should be available throughout the learning process. As mentioned above, one acknowledged limitation of FA is time consuming and labor intensive. Therefore, a lot of time and energy are required of teachers for the formulating of the assessment plan, the designing of learning tasks, the monitoring of the process and giving feedback. It is especially the case at the beginning of the innovation which involves student needs assessment and goal setting and success criteria making. Joint efforts of a group of teachers can solve the problem. Besides, effective use of self and peer evaluation are especially called for in the Chinese College English classrooms because of its large class sizes. On the one hand, the ability to self-assess is not only a core educational skill which is necessary for lifelong learning and which it is desirable to develop as part of higher education, but can also provide the opportunity to reduce staff workload (Boud, 1994); on the other hand, it is a means to reduce teacher's workload.

2. FA strategy training for teachers is necessary because FA is professional. As a new educational assessment trend in China, FA requires the intervention of expertise and professionals so as to make it effective. Some data from this study shows the effects of FA are not so obvious with less experienced teachers' class. So without the guidance of systematically-developed cognitive theories, the design of teaching, learning and assessing activities is likely to ad hoc, unsystematic and ineffective in improving achievements for many students (Niemi, 1997). In other words, both theories and domains of knowledge and practice in which they are to be employed must be deeply understood. So it is essential that both in-service teachers and pre-service teachers have evidence-based education or training of FA.

3. Involving students in making success criteria for learning tasks as well as sharing with them the learning outcomes are the crucial step. So doing can help them understand and achieve their goal better and make effective decisions to close the gap between their learning situation and the goal.

4. All assessed tasks or activities should account for one proportion in the FA. Doing so may make students believe every effort they put in the activity is rewarding while making decisions. But it has to be cautioned that being rough is preferable over being specific and letter grade is better than scoring, because marks or grades alone produce no learning gains and students gain the most learning value from assessment when feedback is provided without marks or grades (Crooks, 2001).

5. Quality feedback and self-assessment are always the key concepts and factors of FA. Feedback should be given regularly, timely and it should be specific and encouraging because feedback given as part of FA helps learners become aware of any gaps that exist between their desired goal and their current knowledge, understanding, or skill and guides them through actions necessary to obtain the goal (Ramaprasad, 1983; Saldler, 1989). And specific and encouraging feedback is the most helpful type of feedback to students because the specific comments about errors and specific suggestions for improvement encourages students to focus their attention thoughtfully on the task rather on simply getting the right answer (Bangert-Drowns, Kulick, \& Morgan, 1991; Elawar \& Corno, 1985). This type of feedback may be particularly helpful to lower achieving students because it emphasizes that students can improve as a result of effort rather than be doomed to low achievement due to some presumed lack of innate ability because FA helps support the expectation that all children can learn to high levels and counteracts the cycle in which students attribute poor performance to lack of ability and therefore become discouraged and unwilling to invest in further learning (Ames, 1992; Vispoel \& Austin, 1995).

As for self-assessment, it is recognized as a formative process leading to self-development (Klennowski, 1996). According to Entwistle (1993), when students are engaged in evaluating their own work, they are thinking about what they have learned and how they learn. They are consequently more aware of their thinking and learning processes which encourages a deep, as opposed to a surface, approach to learning. These are processes which need to be fostered if we wish students to succeed (National Commission On Education, 1993).

To conclude, with so many potential advantages and benefits empirically and theoretically and recognized as assessment for learning instead of assessment of learning by so many researchers, FA is strongly recommended to be integrated into College English classrooms in China as a necessary supplement to summative assessment. Its appropriate use will produce substantial and empowering impact on student learning.

\section{REFERENCES}

[1] Ames, C. (1992). Classrooms: Goals, structures, and student motivation. Journal of Educational Psychology, 84 (3): $261-271$.

[2] Assessment Reform Group, U.K. (1999). Assessment for learning: beyond the black box. Cambridge. U.K: University of Cambridge School of Education.

[3] Black, P., \& William, D. (1998a). Assessment and classroom learning. Assessment in Education, 5 (1): 7-74. 
[4] Black, P. and William, D. (1998b). Inside the black box: Raising standards through classroom assessment. Phi Delta Kappan, 80 (2): 139-148. (Available online: http://www.pdkintl.org/kappan/kbla9810.htm.)

[5] Boud, D. (1994).The move to self-assessment: liberation or a new mechanism for oppression? Education Line, 1997.

[6] Cowie, B., \& Bell, B. (1996). A model of FA in science education. Assessment in Education, 6, 101-116.

[7] Crooks, T. J. (1988). The impact of classroom evaluation practices on students. Review of Educational Research, 58, 438-481.

[8] Crooks, T. (2001).The Validity of FAs. Paper presented at 2001 Annual Meeting of the British Educational Research Association (BERA).Leeds, England, 13 - 15 September

[9] Elawar, M.C., \& Corno, L. (1985). A factorial experiment in teachers' written feedback on student homework: Changing teacher behaviour a little rather than a lot. Journal of Educational Psychology, 77 (2): 162-173.

[10] Entwistle, N. (1993). Teaching and the Quality of Learning, Report of a seminar held on 25 November, London: Committee of Vice-Chancellors and Principals of the Universities of the United Kingdom and Society for Research into Higher Education.

[11] Gipps, C., McCallum, B., \& Hargreaves, E. (2000). What makes a good primary school teacher? London: Routledge Falmer.

[12] Guo, Q. \& Yang, zhi. Q. (2003). Formative Assessment and College English Teaching and Testing (In Chinese), Research On Education Tsinghua University, Vol.24, No 5, pp103-108.

[13] Ministry of Education, New Zealand. (1994). Assessment: policy to practice. Wellington, New Zealand: Learning Media.

[14] National Commission on Education. (1993). Learning to Succeed A Radical Look at Education Today and A Strategy for the Future. London: Heinemann.

[15] Niemi, D. (1997). Cognitive Science, Expertise-Novice Research, and Performance Assessment. Theory into Practice, 36(4).

[16] Olson, L. (2005). Classroom Assessments Stir Growing Global Interest. Education Week. Washington: October 5, 2005.Vol. 25, Iss.6, p.8.

[17] Pausch, L.M. \& Popp, M.P. (1997). Assessment of Information Literacy: Lessons from the Higher Education Assessment Movement. Retrieved October 30, 2001, from http://www.ala.org/acrl/paperhtm/d30.html

[18] Ramaprasad, A. (1983). On the definition of feedback. Behavioral Science, 28 (1): 4-13.

[19] Tan, H. Y. (2004). Using Formative Assessment Strategies to Aid Students' Learning in Adult English Teaching as Foreign Language-An Experimental Study.

[20] Vispoel, W.P., and Austin, J.R. (1995). Success and failure in junior high school: A critical incident approach to understanding students' attributional beliefs. American Educational Research Journal, 32 (2): 377-412.

[21] Xue, M. (2006). A study of FA in College EFL Learning and Teaching.

[22] Xu, B.X., (2003). On the FA of EFL Students: From Theory to Practice.

[23] Zhou, H. M. \& Cai, Zh. Y. (2006). An Experiment on Implementation of Formative Assessment and the Reform of the Current Assessing System of College English Teaching (in Chinese). Journal of Jiangxi Normal University (Philosophy and Social Sciences Edition), Vol. 39 (1): 114-118.

Liqiu Wei was born in Guangxi, China in 1967. She received her M.A. degree in linguistics from Guangdong University of Foreign Studies, China in 2008.

She is currently an associate professor in the department of Foreign Languages, Hechi University, Guangxi, China. Her research interests include English language teaching, second language acquisition and foreign language teacher development. 